\title{
THE GENETIC ANALYSIS OF BARLEY STORAGE PROTEINS
}

\author{
P. R. SHEWRY,* AUDREY J. FAULKS,* R. A. PICKERING, $\uparrow$ I. T. JONES,
}

R. A. FINCHI and B. J. MIFLIN*

* Biochemistry Department, Rothamsted Experimental Station, Harpenden, Herts, AL5 2JO; $\uparrow$ Welsh Plant Breeding Station, Plas Gogerddan, Aberystwyth, Dyfed SY23 3EB; † Plant Breeding Institute, Maris Lane, Trumpington, Cambridge CB2 2LQ

Received 30.xi.79

\section{SUMmaRY}

\begin{abstract}
Hordein polypeptide patterns in barley seeds are known to be controlled by structural genes at 2 loci, Hor-1 and Hor-2, on chromosome 5 . Twodimensional and high resolution one-dimensional electrophoretic analyses of seeds of $\mathrm{F}_{2}$ and doubled haploid progenies of four intervarietal crosses gave no evidence of recombination within these loci. Genetic analysis of the progenies showed that Hor -1 is $0.161+0.026$ centimorgans from Hor-2 and the mildew resistance locus, $M l a$, lies between them, $0.064 \pm 0.020$ centimorgans from Hor -1 and $0 \cdot 082+0 \cdot 024$ centimorgans from Hor-2.
\end{abstract}

\section{INTRODUCTION}

THE storage protein fraction of barley (hordein) accounts for up to 50 per cent of the total grain N. When separated on the basis of molecular weight by sodium dodecyl sulphate-polyacrylamide gel electrophoresis (SDSPAGE) the polypeptides can be classified into three groups " $A$ ", " $B$ ", and " $C$ " (Koie, Ingversen, Andersen, Doll and Eggum, 1976; Miflin and Shewry, 1977a) of which only the " $B$ " and " $C$ " are thought to be true storage proteins (Miflin and Shewry, 1977b). Further separation into around 10-20 polypeptides (depending upon variety) can be achieved using two-dimensional (2-D) methods combining isoelectric focusing (IEF) in the first dimension with SDS-PAGE in the second (Shewry, Pratt, Faulks, Parmar and Miflin, 1979; Shewry, Ellis, Pratt and Miflin, 1978a).

The " $C$ " hordeins differ from the " $B$ " in having a greater content of glutamine, proline and phenylalanine and less lysine and sulphur amino acids, which results in differences in solubility and extraction behaviour (Shewry, Field, Kirkman, Faulks and Miflin, 1980; Miflin and Shewry, 1979). Oram, Doll and Koie (1975) showed that the " $B$ " hordein pattern was determined by co-dominant alleles at a locus (later called Hor-2) linked to $M l a$ on chromosome 5 . It has since been shown that the " $C$ " pattern is controlled by a second locus (called Hor-1) which is linked to Hor-2 although the linkage of the Hor-1 locus to Mla was not reported (Shewry, Pratt, Finch and Miflin, 1978c; Doll and Brown, 1979). Recently, Sozinov, Netsvetaev, Grigoryan and Obrazbsov (1978) have reported that the hordein pattern in var. Steporoy is controlled by five linked loci (termed Hrd $A-E$ ) of which $H r d A$ and $H r d B$ appear to correspond to Hor-1 and $H o r-2$ respectively. The nature of the proteins coded by $\operatorname{Hrd} C, D$ and $E$ is uncertain but they are present at low concentrations in the " $C$ " hordein region of starch gels. These five loci, however, are based on the frequencies 
of phenotypic classes in a homozygous $F_{15}$ population and although the $\operatorname{Hrd} A$ and $H r d B$ loci have been confirmed by studying $\mathrm{F}_{2}$ frequencies (Sozinov et al., 1978) and crosses involving translocations (Netsvetaev, 1978), $\operatorname{Hrd} C, D$ and $E$ remain to be confirmed.

The previous studies have failed to show recombination within either locus, although peptide mapping (Miflin and Shewry, 1979; Miflin, Matthews, Burgess, Faulks and Shewry, 1979) suggests that the individual polypeptides within the " $B$ " group are the products of separate genes. This failure may have been due to the use of one-dimensional (1-D) analytical systems in which co-migration of polypeptides occurs (Shewry et al., $1978 a, 1979)$. We decided, therefore, to make a detailed study of the genetic control of hordein using 2-D and high-resolution 1-D analyses. We have used both $F_{2}$ material and, to eliminate the problems posed by scoring heterozygous triploid endosperms, doubled monoploid lines produced by the Hordeum bulbosum technique. Varieties with mildew resistance genes of the Mla complex on chromosome 5 were used so as to determine the position of this locus relative to both Hor 1 and Hor 2 .

\section{Materials AND methods}

\section{(i) Material}

Table 1 shows the parental lines, their hordein patterns and their mildew resistance alleles. Previously known hordein patterns are presumed to be governed by single alleles at Hor-1 ( $C$-bands) and Hor 2 ( $B$-bands) named after the standard varieties containing them, viz. Proctor ( $\mathrm{Pr})$, Aramir ( $\mathrm{Ar}$ ),

\section{TABLE 1}

Parental lines and their hordein patterns and mildew resistance alleles. All loci are on chromosome 5 except Mlg on chromosome 4 and Mlv whose location is unknown

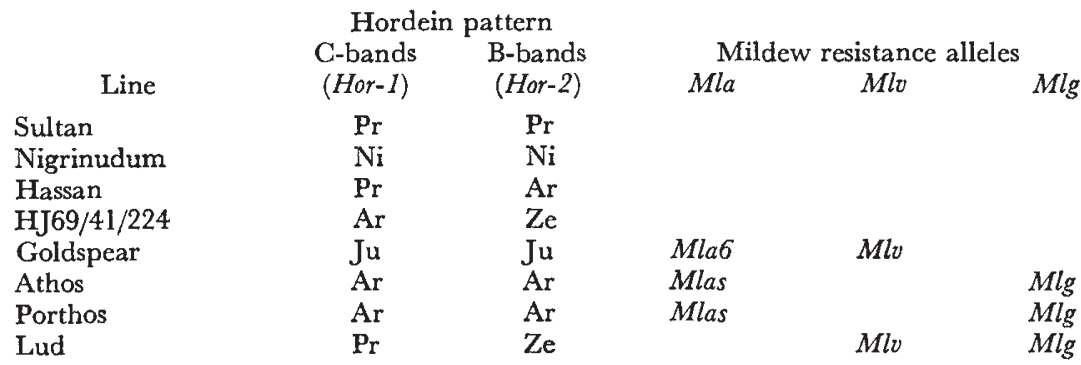

Zephyr (Ze) and Jupiter (Ju) (Shewry, Pratt and Miflin, 1978b). Nigrinudum has a new pattern and its presumed Hor-1 and Hor-2 alleles are designated Ni. This variety is the only one used which has the dominant allele at the black lemma locus $(B)$ on chromosome 5. Mildew resistance genes are named as in Wolfe and Schwarzbach (1978). For genetic analysis, $\mathrm{F}_{2}$ seeds were used from cross 1 (Nigrinudum $\times$ Sultan) but doubled haploid lines were obtained from $F_{1}$ plants of crosses 2 (Hassan $\times H$ J69/41/224), 3 (Goldspear $\times$ Athos) and 4 (Porthos $\times$ Lud) by methods similar to those described by Kasha and Kao (1970) and by Jensen (1976). The methods involved pollinating the intraspecific $\mathrm{F}_{1}$ plants with Hordeum bulbosum pollen, 
culturing the interspecific hybrid embryos so that the $H$. bulbosum genome was eliminated and diploidising the resultant barley haploids with colchicine. Such doubled haploids are homozygous and genetically equivalent to an unbiased sample (Kasha and Reinbergs, 1976) of diploidised eggs from the intraspecific $F_{1}$. Doubled haploid lines were multiplied in the glasshouse and field. In cross 4 , only lines resistant to mildew in a field trial were used for genetic analysis.

\section{(ii) Hordein pattern analysis}

Hordein fractions were extracted from half seed of cross 1 as described previously (Shewry et al., 1978b). They were dissolved in $50 \mu \mathrm{l}$ of $8 \mathrm{~m}$ urea and 1 per cent (v/v) 2-mercaptoethanol, alkylated with 4-vinylpyridine $(1.5$ per cent $\mathrm{v} / \mathrm{v}$ ) and $25 \mu \mathrm{l}$ aliquots used for $2-\mathrm{D}$ analysis. The remaining $25 \mu \mathrm{l}$ was dialysed against 1 per cent $(\mathrm{v} / \mathrm{v})$ SDS for $1-\mathrm{D}$ analysis.

Five seeds of the Hassan $\times$ HJ69/41/224, Porthos $\times$ Lud and Goldspear $\times$ Athos lines were extracted by crushing with a hammer and stirring for 1 hour at $60^{\circ}$ with $10 \mathrm{ml}$ of 50 per cent $(\mathrm{v} / \mathrm{v})$ propan-1-ol 2 per cent 2-mercaptoethanol (Shewry et al., 1978a). After centrifugation, the tissue was reextracted by suspending in a sonic bath for $30 \mathrm{~min}$ with $5 \mathrm{ml}$ of the same solvent. Hordein was precipitated from the bulked supernatants by the addition of 2 vols $0.75 \mathrm{M} \mathrm{NaCl}$ and standing overnight at $4^{\circ} \mathrm{C}$. It was then reduced and either pyridylethylated or cyanoethylated (Shewry et al., $1978 a$ ).

The fractions were separated by 1-D SDS-PAGE in 17.5 per cent acrylamide gels at $p \mathrm{H} 8.9$, IEF in 5 per cent polyacrylamide in the $p \mathrm{H}$ range 5-9 or a 2-D procedure combining both systems (Shewry et al., 1978a).

Cross 1 was analysed by 1-D SDS-PAGE and 2-D analysis (figs. 1 and 2). The " $B$ " hordein was more completely resolved by the 2 -D system (fig. 2) and was scored from these gels. Because of the diffuseness and poor staining reaction of the " $\mathrm{G}$ " polypeptides on the 2-D gels, this group was also scored from the 1-D separations (fig. 1). Four classes each of "B" and " $\mathrm{G}$ " patterns could be recognised in the $\mathrm{F}_{2}$ progeny. These were the two homozygous parental patterns (figs. $1(a),(b) ; 2(a),(b))$ and two types of heterozygote in which a weak pattern from one parent co-existed with a stronger pattern from the other (Figs. $1(c),(d) ; 2(c),(d))$. These were interpreted as due to differences in the dosage of alleles from the male and female gametes.

Examination of the gels indicated that there was no recombination within either Hor locus. However, it was difficult to score for gene dosage in the heterozygotes, especially in the 2-D gels. In crosses 2-4, therefore, several seeds were used from each doubled haploid line for 1-D SDS-PAGE analysis and, in crosses 2 and 3, for 2-D analysis (fig. 3).

\section{(iii) Mildew tests}

In crosses 3 and 4, reactions of each doubled haploid line to isolates of powdery mildew (Erysiphe graminis DG f.sp. hordei Marchal) were scored on several seedlings in tests carried out in spore-proof conditions. Isolates $\mathrm{AB} 3(V-a 6, V-a s, V-g), \mathrm{AB} 14(V-a 6, V-v, V-g), \mathrm{CCl}(V-a s)$ and $\mathrm{CC15}(V-a 6$, $V-v)$ were inoculated singly onto different subsamples of each line in cross 3 but only $\mathrm{AB} 3$ and $\mathrm{ABI} 4$ were used in cross 4. 
Seedlings were scored as either resistant or susceptible based on the mildew recording scale 0-4 used by Jones and Pickering (1978). Plants with reaction type $0-2$ were classified as resistant and with 3 or 4 as susceptible.

\section{(iv) Genetic analysis}

When linkage between two loci was detected, it was estimated by methods described by Bailey (1961). In populations of $n$ plants where $a$ and $d$ were the frequencies of parental phenotypes and $b$ and $c$ the frequencies of recombinant phenotypes, the recombination fraction, $p$ was calculated as $(b+c) / \mathrm{n}$, or when allelic ratios at both loci differed significantly from $1: 1$, as $\sqrt{ }(b c) /(\sqrt{ }(b c)+\sqrt{ }(a d)$. The standard error of $p$ was calculated as $\sqrt{ }\left(\left(p-p^{2}\right) / n\right)$ or as $1 / 2\left(p-p^{2}\right) \sqrt{ }(1 / b+1 / c+1 / a+1 / d)$, respectively. Map distances were calculated as $-1 / 2 \log _{n}(1-2 p)$ with standard error (s.e. of p) $/(1-2 p)$.

\section{Results}

Table 2 gives phenotype frequencies in progenies of crosses 1-4. There was no sign of recombination within a $C$-band pattern or a $B$-band pattern and so Hor-1 and Hor-2 were treated as simple loci with multiple alleles.

\section{TABLE 2}

Frequencies in progeny of crosses $1-4$ of phenotypes governed by 8 pairwise combinations of the loci, Hor-1, Hor-2, Mla, Mlv and B.

\begin{tabular}{|c|c|c|c|c|c|c|}
\hline \multirow[b]{3}{*}{$\begin{array}{l}\text { Governing } \\
\text { locus } 1\end{array}$} & \multirow[b]{3}{*}{$\begin{array}{c}\text { Governing } \\
\text { locus } 2\end{array}$} & & \multicolumn{4}{|c|}{ Phenotype frequency } \\
\hline & & & \multicolumn{2}{|c|}{$\begin{array}{l}\text { Parental types: } \\
\text { maternal allele } \\
\text { expressed at }\end{array}$} & \multicolumn{2}{|c|}{$\begin{array}{c}\text { Recombinant types: } \\
\text { maternal allele } \\
\text { expressed at }\end{array}$} \\
\hline & & Cross & $\begin{array}{l}\text { both } \\
\text { loci }\end{array}$ & $\begin{array}{l}\text { neither } \\
\text { loci }\end{array}$ & $\begin{array}{c}\text { locus } \\
1\end{array}$ & $\begin{array}{c}\text { locus } \\
2\end{array}$ \\
\hline \multirow[t]{4}{*}{ Hor-1 } & Hor-2 & $\begin{array}{l}\text { 1. (O) } \\
1 .(ठ) \\
2 . \\
3 . \\
4 .\end{array}$ & $\begin{array}{l}28 \\
30 \\
11 \\
45 \\
53\end{array}$ & $\begin{array}{l}30 \\
30 \\
12 \\
33 \\
27\end{array}$ & $\begin{array}{l}7 \\
3 \\
2 \\
9 \\
4\end{array}$ & $\begin{array}{r}3 \\
5 \\
3 \\
2 \\
10\end{array}$ \\
\hline & Mla & $\begin{array}{l}3 . \\
4 .\end{array}$ & $\begin{array}{l}51 \\
56\end{array}$ & $\begin{array}{l}34 \\
31\end{array}$ & $\begin{array}{l}3 \\
1\end{array}$ & $\begin{array}{l}1 \\
6\end{array}$ \\
\hline & $M l v$ & $\begin{array}{l}3 . \\
4 .\end{array}$ & $\begin{array}{l}30 \\
12\end{array}$ & $\begin{array}{l}13 \\
30\end{array}$ & $\begin{array}{l}24 \\
45\end{array}$ & $\begin{array}{r}22 \\
7\end{array}$ \\
\hline & $B$ & $\begin{array}{l}\text { 1. }(q) \\
1 .(\delta)\end{array}$ & $\begin{array}{l}13 \\
16\end{array}$ & $\begin{array}{l}9 \\
9\end{array}$ & $\begin{array}{l}6 \\
6\end{array}$ & $\begin{array}{l}16 \\
13\end{array}$ \\
\hline \multirow[t]{3}{*}{ Hor-2 } & Mla & $\begin{array}{l}3 . \\
4 .\end{array}$ & $\begin{array}{l}46 \\
59\end{array}$ & $\begin{array}{l}36 \\
28\end{array}$ & $\begin{array}{l}1 \\
4\end{array}$ & $\begin{array}{l}6 \\
3\end{array}$ \\
\hline & $M l v$ & $\begin{array}{l}3 . \\
4 .\end{array}$ & $\begin{array}{l}26 \\
13\end{array}$ & $\begin{array}{l}16 \\
25\end{array}$ & $\begin{array}{l}21 \\
50\end{array}$ & $\begin{array}{r}26 \\
6\end{array}$ \\
\hline & $B$ & $\begin{array}{l}\text { 1. }(q) \\
\text { 1. }\left(0^{2}\right)\end{array}$ & $\begin{array}{l}15 \\
18\end{array}$ & $\begin{array}{l}7 \\
9\end{array}$ & $\begin{array}{l}9 \\
7\end{array}$ & $\begin{array}{l}18 \\
15\end{array}$ \\
\hline Mla & $M l v$ & $\begin{array}{l}3 . \\
4 .\end{array}$ & $\begin{array}{l}28 \\
14\end{array}$ & $\begin{array}{l}13 \\
27\end{array}$ & $\begin{array}{l}24 \\
48\end{array}$ & $\begin{array}{r}24 \\
5\end{array}$ \\
\hline
\end{tabular}




\section{Plate I}

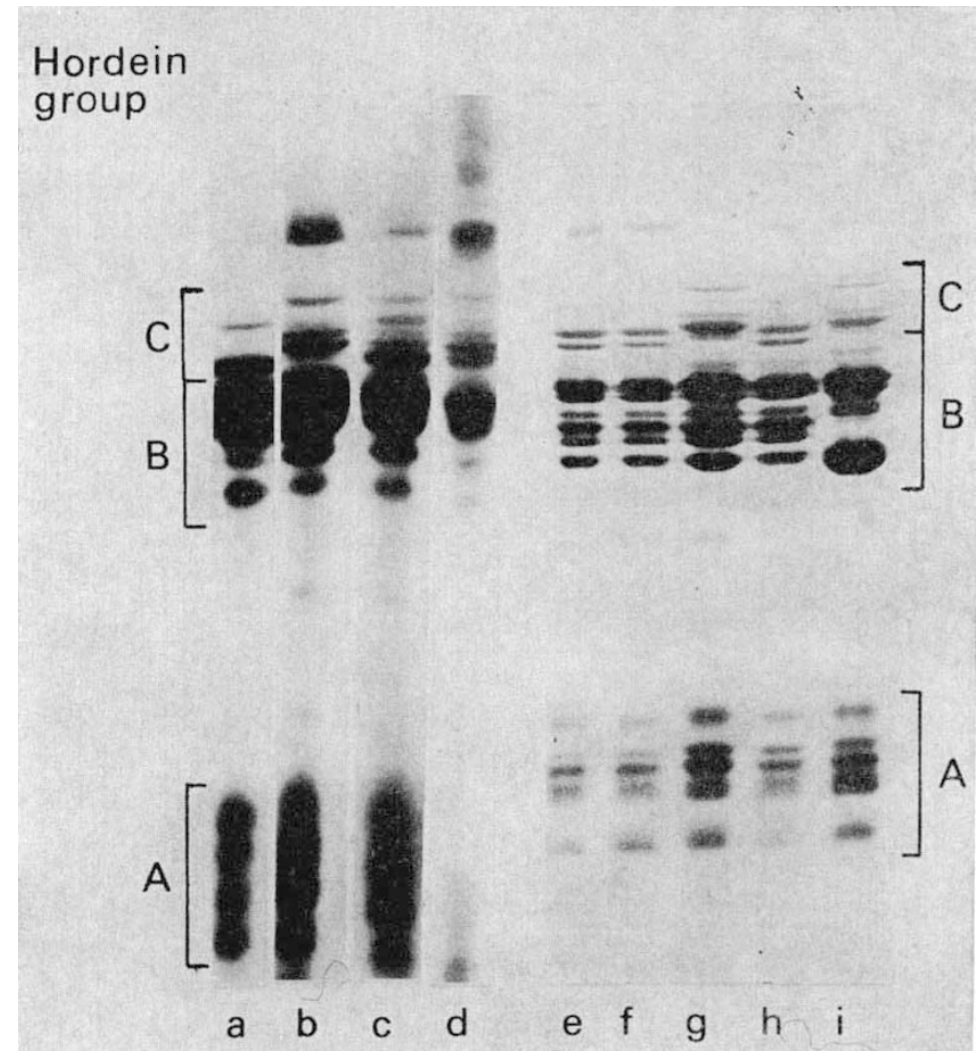

FIG. 1.-SDS-PAGE of pyridylethylated hordeins from $\mathrm{F}_{2}$ half-seeds of cross $1((a)-(d))$ and single doubled haploid seeds of cross $4((e)-(i))$. B-band patterns are not scorable in (a)-(d). (a) Hor-1 Ni,Ni,Ni; (b) Hor-1 Pr,Pr,Pr; (c) Hor-1 Ni,Ni,Pr; (d) Ni,Pr,Pr; $(e),(f),(h)$ Hor-1 Ar,Ar,Ar/Hor-2 Ar,Ar,Ar; $(g)$ Hor-1 Pr,Pr,Pr/Hor-2 Ar,Ar,Ar; $(i)$ Hor-1 $\operatorname{Pr}, \operatorname{Pr}, \operatorname{Pr} /$ Hor-2 Ze,Ze,Ze. 
Plate II

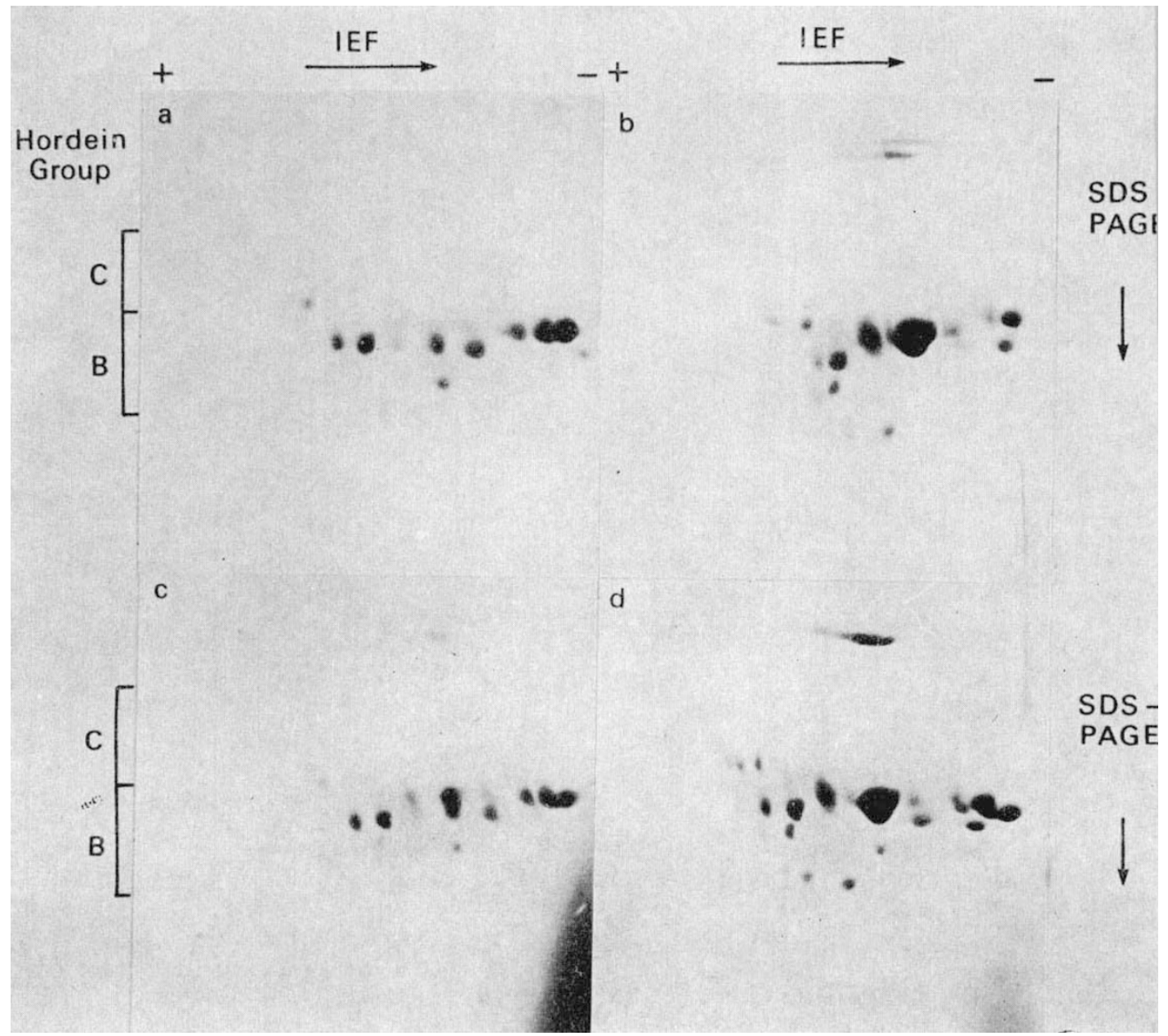

Fig. 2.-Two-dimensional analysis of pyridylethylated hordeins from $\mathrm{F}_{2}$ half-seeds of cross 1 . Hor- 1 alleles are not scorable; Hor-2 alleles are $(a) \mathrm{Pr}, \mathrm{Pr}, \mathrm{Pr} ;(b) \mathrm{Ni}, \mathrm{Ni}, \mathrm{Ni} ;(c)^{\circ} \mathrm{Ni}, \mathrm{Pr}, \mathrm{Pr}$; (d) $\mathrm{Ni}, \mathrm{Ni}, \mathrm{Pr}$. 


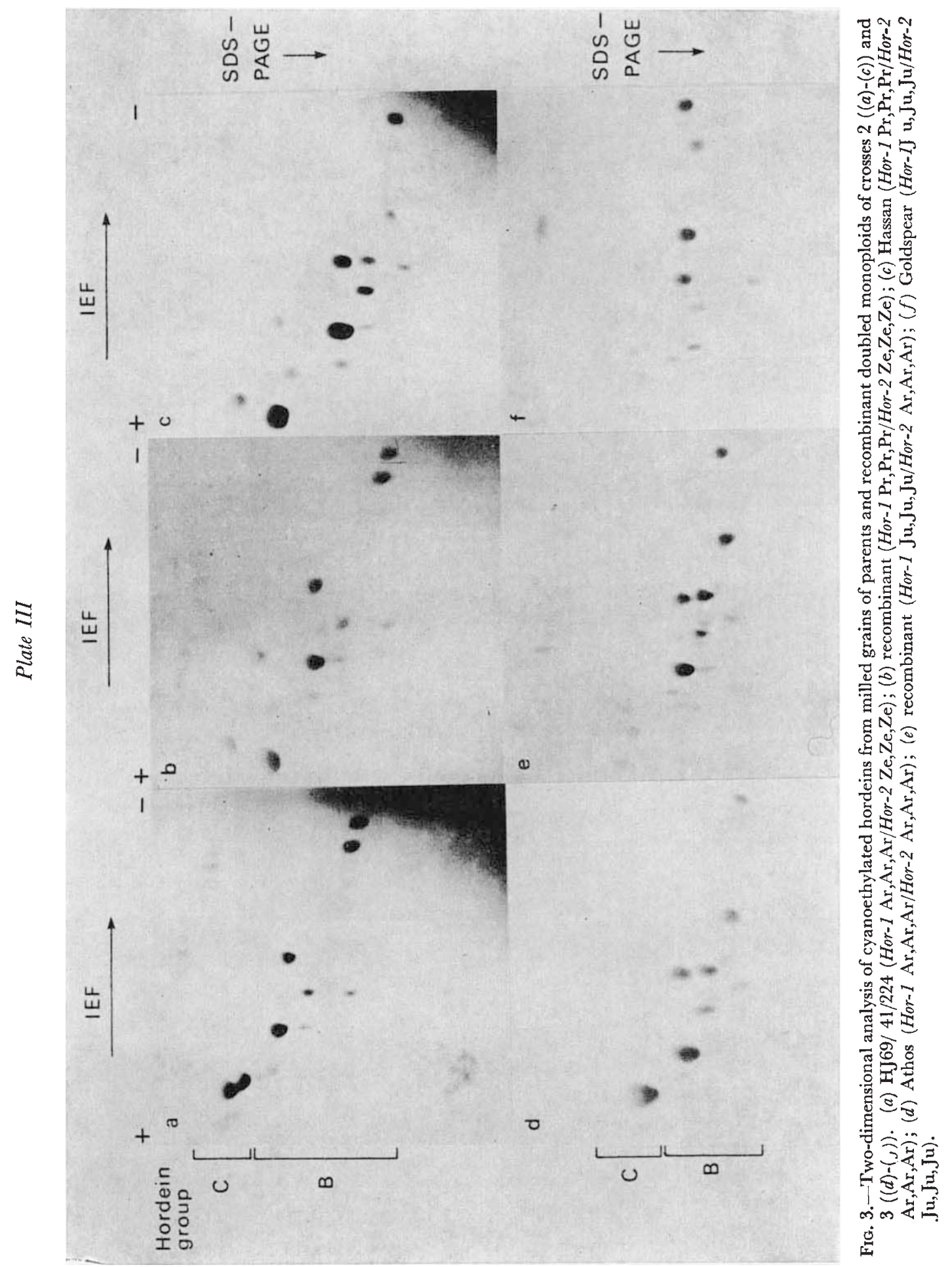


Most alleles segregated in the expected Mendelian ratios except mildew resistance alleles in cross 4 where selection for resistance had been practised. Other cases where allelic ratios deviated from those expected were still included in linkage estimates since the linkage data were homogenous. Hor-1, Hor-2 and Mla were linked with one another but $B$ and Mlv showed no linkage. Table 3 gives recombination fractions and map distance estimates between the linked loci, Hor-1, Hor-2 and Mla. Pooled data showed that Mla lies between Hor-1 and Hor-2 at distances of $0.064 \pm 0.020 \mathrm{cM}$ and $0.082 \pm 0.024 \mathrm{cM}$ from each, respectively. The sum of these separate estimates $(0.146)$ agrees well with the pooled estimate $(0.161+0.026)$ of the largest distance, Hor-1 to Hor-2. In cross 4 genes for yellow rust resistance

TABLE 3

Recombination fractions and map distances between Hor-1, Hor-2 and Mla in crosses 1-4.

\begin{tabular}{|c|c|c|c|c|}
\hline Locus 1 & Locus 2 & Cross & $\begin{array}{l}\text { Recombination } \\
\text { fraction }\end{array}$ & Map distance in $\mathrm{cM}$ \\
\hline \multirow[t]{2}{*}{ Hor-1 } & Hor-2 & $\begin{array}{l}\text { 1. }\left((+)^{*}\right. \\
\text { 1. }\left(J^{*}\right) \\
\text { 1. }\left(++\sigma^{\top}\right) \\
\text { 2. } \\
\text { 3. } \\
\text { 4. } \\
\text { 1. }+2 .+3 .+4 .\end{array}$ & $\begin{array}{l}0 \cdot 147 \pm 0.043 \\
0 \cdot 118 \pm 0.039 \\
0.132 \pm 0.029 \\
0.179 \pm 0.072 \\
0 \cdot 124 \pm 0.035 \\
0 \cdot 149 \pm 0.037 \\
0.138 \pm 0.019\end{array}$ & $\begin{array}{l}0.174 \pm 0.061 \\
0 \cdot 134 \pm 0.051 \\
0 \cdot 154 \pm 0.040 \\
0.222 \pm 0.112 \\
0 \cdot 142 \pm 0.046 \\
0 \cdot 177 \pm 0.052 \\
0.161 \pm 0.026\end{array}$ \\
\hline & Mla & $\begin{array}{l}3 . \\
4 . \\
3 .+4 .\end{array}$ & $\begin{array}{l}0.045 \pm 0.022 \\
0.075 \pm 0.027 \\
0.060 \pm 0.018\end{array}$ & $\begin{array}{l}0 \cdot 047 \pm 0 \cdot 024 \\
0 \cdot 081 \pm 0 \cdot 032 \\
0 \cdot 064 \pm 0.020\end{array}$ \\
\hline Hor-2 & Mla & $\begin{array}{l}3 . \\
4 . \\
3 .+4 .\end{array}$ & $\begin{array}{l}0.079 \pm 0.029 \\
0.079 \pm 0.029 \\
0.076 \pm 0.020\end{array}$ & $\begin{array}{l}0.086 \pm 0.034 \\
0.086 \pm 0.034 \\
0.082 \pm 0.024\end{array}$ \\
\hline
\end{tabular}

* The $q$ and $\delta$ refer to the gametic genotypes deduced as previously (Shewry et al., $1978 c)$.

were also present, the $T_{r} 4$ gene, which is located on chromosome 5, in Lud and an unlocated gene derived from Arabische in Porthos. It was not possible to distinguish between the presence of these two genes in many of the lines from this cross. However, of the 28 lines thought to have the Yr4 gene 22 were Hor $1 \mathrm{Pr}, \mathrm{Hor} 2 \mathrm{Ze}$, four were Hor $1 \mathrm{Pr}, \mathrm{Hor} 2 \mathrm{Ar}$ and one each were Hor $1 \mathrm{Ar}, \mathrm{Hor} 2 \mathrm{Ze}$ and Hor $1 \mathrm{Ar}, \mathrm{Hor} 2 \mathrm{Ar}$. This indicates that the Hor 1 locus is located more closely to the $\operatorname{Rr} 4$ locus than the Hor 2 locus.

\section{Discussion}

The study confirms the previously reported linkage between the Hor 1 and Hor 2 loci. Our pooled estimate of $0.138 \pm 0.019$ for the recombination fraction agrees well with the estimates of Shewry et al. (1978c), Doll and Brown (1979) and Netsvetaev (1978), but is about twice that of Sozinov et al. (1978). We found no evidence for additional hordein loci as described by Sozinov et al. (1978). Although we have examined the equivalent of a total of 347 gametes (253 by 2-D analysis), we have found no evidence of recombination within either the Hor 1 or Hor 2 loci. However, with this number of analyses it is unlikely ( 5 per cent probability) that recombination 
occurring within a map distance of about $0.010 \mathrm{cM}$ would have been detected. These results are thus not inconsistent with previous proposals that these are complex loci.

The mildew resistance data show that Hor 1 and Hor 2 are located on either side of the Mla locus on chromosome 5 . The results from cross 4 with the $Y_{r} 4$ gene tentatively suggest that Hor 1 is on the centromere side of Mla. Recent work by J. Jensen and colleagues (pers. commun.) using Mla and $M l k$ provides much stronger evidence for this conclusion.

The close linkage of Hor 1 and Hor 2 with Mla (and Mlk Jensen pers. commun.) results in the association of certain types of mildew resistance with specific hordein alleles. In some cases the hordein alleles are derived from exotic varieties which have been introduced into breeding programmes as a source of disease resistance. For example, the Hor $1 \mathrm{Ar}$ alleles are associated with the Mlas gene and are derived from the exotic variety Arabische. Of 15 varieties which have the Mlas gene, 11 were found to have the $\mathrm{Hor} 1 \mathrm{Ar}$ and $\mathrm{Hor} 2 \mathrm{Ar}$ alleles while two more had the Hor $2 \mathrm{Ar}$ allele associated with the Hor 1 Pr allele (Shewry et al., 1979).

The linkage with $M l a$ also means that hordein analysis can be used as an initial screen for disease resistance and vice versa in breeding programmes. The analyses can be made on half of either the $F_{1}$ or $F_{2}$ seed, and the embryo half retained to be germinated. Because the hordein alleles are readily scored in the seed, they are also of potential value as markers for the fine structural mapping of chromosome 5 .

Acknowledgments. - The authors wish to thank Mrs H. M. Wall and Mrs S. Parmar for help with SDS-PAGE, Mr P. W. Morgan for assistance with the production of haploids and $\mathrm{Mr}$ R. B. Clothier for help with the rust genes. We are grateful to Dr D. T. Canvin for suggesting the use of doubled monoploids for this type of study and to Dr M. S. Wolfe for some of the mildew strains and for helpful discussion on mildew genes. The work at Rothamsted was supported by EEC grant 000473.

\section{REFERENGES}

BAILEY, N. T. J. 1961. Introduction to the mathematical theory of linkage. Oxford University Press.

DOLL, H., AND BROWN, A. D. H. 1979. Hordein variation in wild (Hordeum spontaneum) and cultivated (Hordeum vulgare) barley. Can. F. Genet. Cytol., 21, 391-404.

JONES, I. T., AND PICKERING, R. A. 1978. The mildew resistance of Hordeum bulbosum and its transference into $H$. vulgare geneotypes. Ann. appl. Biol. 88, 295-298.

JENSEN, G. J. 1976. Barley monoploids and doubled monoploids: techniques and experience. In Barley Genetics III, ed. H. Gaul, pp. 316-345. Karl Thiemig, München.

KASHA, K. J., AND KAO, K. N. 1970. High frequency haploid production in barley (Hordeum vulgare L.). Nature (Lond.), 225, 874-876.

KASHA, K. J., AND REINBERGS, E. 1976. Utilization of haploidy in barley. In Barley Genetics III, ed. H. Gaul, pp. 307-315. Karl Thiemig, München.

KOIE, B., INGVERSEN, J., ANDERSEN, A. J., DOLL, H., AND EGGUM, B. o. 1976. In Evaluation of Seed Protein Alterations by Mutation Breeding. IAEA, Vienna, pp. 55-61.

Miflin, B. J., Matthews, J. A., BURgess, s. R., FaUlKs, A. J., ANd SheWry, P. R. 1979. The synthesis of barley storage proteins. Proc. of $\mathcal{N} A T O / F E B S$ Symposium on Plant Genome Expression, ed. C. J. Leaver, Plenum Press, pp. 233-243.

MIFLIN, B. J., AND SHEWRY, P. R. 1977a. An introduction to the extraction and characterisation of barley and maize proteins. In Techniques for the Separation of Barley and Maize Proteins, eds. B. J. Millin and P. R. Shewry. EEC, Luxembourg, pp. 13-25.

MIFlin, B. J., AND SHEWry, P. R. 1977b. Eds. Techniques for the Separation of Barley and Maize Proteins. EEG, Luxembourg. 
MIFLIN, B. J., AND SHEWRY, P. R. 1979. The biology and biochemistry of cereal seed prolamins. In Seed Protein Improvement in Cereals and Grain Legumes. IAEA, Vienna, pp. 137-158.

NETSvetaev, v. P. 1978. (The authors translation of) Mapping of hordein loci in chromosome 5 of barley with the help of reciprocal translocations. Biologischeskie Osmovy Ratseonalnogo Ispolzovaniya Firotnugo 1 Rastitelnogo Myra, USSR Riga, Zinatne, pp. 145-146.

ORAM, R. W., DOLL, H., AND KOIE, B. 1975. Genetics of two storage protein variants in barley. Hereditas, 80, 53-58.

SHEWRY, P. R., ELLIS, J. R. S., PRATT, H. M., AND MIFLIN, B. J. 1978a. A comparison of methods for the extraction and separation of hordein fractions from 29 barley varieties. 7 . Sci. Fd. Agric. 29, 433-441.

SHEWRY, P. R., PRATT, H. M., AND MIFLIN, B. J. 1978b. Varietal identification of single seeds of barley by analysis of hordein polypeptides. F. Sci. Fd. Agric., 29, 587-596.

SHEWRY, P. R., PRATT, H. M., FINCH, R. A., AND MIFLIN, B. J. 1978c. Genetic analysis of hordein polypeptides from single seeds of barley. Heredity, 40, 463-466.

SHEWRY, P. R., PRATT, H. M., FAULKS, A. J., PARMAR, s., AND MIFLIN, B. J. 1979. The storage protein (hordein) polypeptide pattern of barley (Hordeum vulgare L.) in relation to varietal identification and disease resistance. F. natn. Inst. Agric. Bot., 15, 34-50.

SHEWRY, P. R., FIELD, J. M., KIRKMAN, M. A., FAULKS, A. J., AND Miflin, B. J. 1980. The extraction, solubility and preliminary characterisation of two groups of barley storage protein (hordein) polypeptides. F. Exp. Bot. (in press).

SOZINOV, A. A., NETSVETAEv, v. P., GRIGORYAN, E. M., AND IBRAZTSOV, I. s. 1978. Mapping of Hrd locuses in barley (Hordeum vulgare L. Emed. Vav et Bacht), Genetika, 16, 1610-1619. WOLFE, M. S., AND SCHWARZBACH, E. 1978. The recent history of the evolution of barley powdery mildew in Europe. In The Powdery Mildews, ed. D. M. Spencer. Academic Press, London, pp. 129-157. 